\title{
Sprawozdanie z realizacji drugiej części projektu pt. Miejsca i motywacje tożsamości. Polacy na Kresach Wschodnich, Odessa, 16-23 listopada 2019 r.
}

W dniach 16-23 XI 2019 r. została zrealizowana druga część projektu badawczo-edukacyjnego Miejsca i motywacje tożsamości. Polacy na Kresach Wschodnich. Został on przygotowany przez studentów Wydziału Historycznego Uniwersytetu im. Adama Mickiewicza w Poznaniu, przy zaangażowaniu prof. UAM dr hab. Agnieszki Sawicz, prof. dr hab. Stanisława Jankowiaka oraz prof. UAM dr hab. Piotra Okulewicza. Tematyka drugiego etapu związana była ze zgłębieniem historii i aktualnej sytuacji zapomnianego pogranicza - pogranicza polsko-mołdawskiego oraz sentymentalnej ziemi, której centrum stanowi Odessa. Celem przedsięwzięcia było zapoznanie się z sytuacją mniejszości polskiej na dawnych Kresach Wschodnich Rzeczypospolitej i dawnym pograniczu I Rzeczypospolitej na południowym wschodzie.

Odessa jest stosunkowo młodym miastem, liczącym nieco ponad 200 lat (oficjalny rok założenia miasta - 1794). Od samego początku istnienia miasto jest zamieszkiwane przez wieloetniczną i wielowyznaniową ludność, czego najlepszym przykładem jest mnogość świątyń różnych wyznań. Odessa została założona jako miasto portowe, dzięki temu możliwy był napływ społeczności związanych z różnymi światowymi kulturami. Założenie miasta przypisuje się Jose Pascual Domingo de Ribas y Boyonos, neapolitańczykowi hiszpańskiego pochodzenia, który w służbie dla carycy Katarzyny II, dowodząc Kozakami, zdobył twierdzę Hadżibej, stanowiącą wtedy przyczółek Imperium Osmańskiego. Deribas, bo tak upraszczano nazwisko Hiszpana, zaproponował carycy budowę portu, tak by zasiedlona ludność utożsamiając się z zamieszkiwaną przez nich ziemią stanowiła naturalną obronę przed żądnym zemsty Imperium. Tak miasto rozwijało się aż do śmierci Katarzyny, po 
której na tron wstąpił Paweł I. Ten cofnął inwestycje w miasto. Na wieść o tym kupcy odescy wysłali do cara znaczną ilość pomarańczy, które niedawno przybyły do portu w Odessie. Car widząc to wznowił dofinansowywanie miasta. Po zmianie na tronie carskim Odessa ponownie odżyła, a dzieło Jose de Ribasa kontynuował Armando Emmanuel Sophie Septimanie du Plessi książę de Richelieu, który walnie przyczynił się do rozkwitu miasta. Warto nadmienić, że przy zakładaniu miasta, na 50 pierwszych rodzin, które przybyły na niezasiedlone jeszcze tereny nadczarnomorskie, gdzie w przyszłości miał powstać port, $30 \mathrm{z}$ nich było pochodzenia polskiego.

Pierwszego dnia pobytu zapoznaliśmy się z okolicą Privoz Market, znajdującego się przy mniej zamożnych dzielnicach Odessy. Następnie udaliśmy się do Muzeum Holocaustu znajdującego się niedaleko naszego miejsca pobytu. Zapoznaliśmy się tam z historią narodowości żydowskiej, która stanowiła bardzo ważną część społeczeństwa odesskiego.

Kolejnego dnia udaliśmy się pod pomnik carycy Katarzyny II Wielkiej, za której panowania zostało założone miasto. Ulica, na której znajduje się ww. monument ma dwie patronki, oprócz carycy, także Świętą Katarzynę. Stało się tak ze względu na kontrowersje związane z postacią rosyjskiej władczyni, których pokłosiem jest wspólny patronat tejże ulicy. Następnie udaliśmy się pod pomnik Armand’a-Emmanuela du Plessis, księcia de Richelieu, który od 1804 r. był gubernatorem Odessy i walnie przyczynił się do rozwoju miasta w jego początkowej fazie. Sama statua znajduje się na szczycie Schodów Potiomkinowskich, które są najbardziej rozpoznawalnym miejscem w Odessie. Nazwa schodów wzięła się od wydarzeń czerwca 1905 r., czyli po sławetnym powstaniu na pancerniku Potiomkin. Z uwagi na ich monumentalny wygląd, wcześniej mówiono o nich gigantyczne bądź wielkie bulwarne. Zostały wybudowane w latach 1837-1841 jako reprezentacyjne wejście z portu do centrum miasta. Swoją popularność zdobyły przede wszystkim dzięki filmowi S. Esiensteina Pancernik Potiomkin. Stamtąd udaliśmy się do portu, gdzie znajduje się alegoryczny pomnik rodzącej się Odessy. Powstał on ze względu na portowy charakter miasta, odzwierciedla fakt, że to tutaj rodzi się Odessa i bije jej serce. W porcie znajduje się również pomnik Żony żeglarza. Został on postawiony, aby wyrazić tęsknotę rodzin czekających na powrót żeglarzy z rejsów.

O godzinie 15:00 udaliśmy się do Domu Bułgarskiego, gdzie miał miejsce koncert z okazji 101. rocznicy niepodległości Polski. Koncert rozpoczęto od uroczystego odśpiewania całego hymnu Polski Mazurka Dąbrowskiego oraz hymnu Ukrainy Щe не вмерла Україна. Koncert uświetnili swoją obecnością przedstawiciele Konsulatu Generalnego w Odessie, konsul Mateusz Marszałek, konsul Łukasz Winny, referent 
do spraw kultury Justyna Lalik, Kapelan Polonii, ksiądz kanonik Jan Dargiewicz i przedstawiciele organizacji mniejszości narodowych. Uroczystość otworzyła prezes stowarzyszenia Polska Nuta Pani Eugenia Fedczyszyna, a następnie miejscowe dzieci zatańczyły uroczystego poloneza i odczytały patriotyczne wiersze. Wkrótce po tym na scenę wszedł chór Polska Nuta, któremu przewodniczył Wiktor Pajgert. Chórzyści ubrani byli w ludowe stroje polskie i w patetyczny sposób odśpiewali kilka pieśni patriotycznych, w tym m.in. Bogurodzicę. Kolejny etap koncertu otworzyli miejscowi artyści Dawid Kazancew, Marina Tereszyna, Julia Timakowa, Zachar Dubowy oraz Aleksander Niczyporczuk. Ponownie na scenie zagościł ww. chór, który przedstawił nam swój lżejszy repertuar, odśpiewując interpretacje utworów Autostop, Nigdy więcej, Nie o tobie dzisiaj myślę, O Chmielu oraz Na jakom pamiontke Moje stawiajom. Zwieńczeniem całego wydarzenia był oberek wykonany przez taneczno-sportowy klub Wiktoria. Po zakończonym koncercie odbyło się rozdanie nagród uczestnikom i zwycięzcom konkursu 101 pytań o Polsce, całość rozdania świetnie poprowadziła Sonia Pajgert. Dla gości koncertu przewidziano poczęstunek.

Wraz z początkiem tygodnia, dzięki uprzejmości członków stowarzyszenia Polska Nuta, mieliśmy przyjemność podążyć szlakiem polskich zabytków pod przewodnictwem Sonii i Wiktora Pajgert. Rozpoczęliśmy od ulicy Deribasowskiej, przy której niegdyś mieścił się dom Adama Mickiewicza, co upamiętnia płaskorzeźba z wizerunkiem patrona naszej uczelni. Na tym samym budynku jest również wizerunek rosyjskiego wieszcza Aleksandra Puszkina. Następnym obiektem, do którego nas zaprowadzono był Pałac Woroncowow wraz z belwederem, który znajdował się nieopodal budynku, a po przejściu przez słynny most teściowej przedstawiono nam Pałac Berliny-Brzozowskiego. W trakcie poznawania miasta, państwo Pajgert przedstawili nam wiele miejscowych wierzeń. Okazało się, że Odesyci, podobnie jak cała narodowość ukraińska, lubują się w przesądach o tym, że odpowiednio potraktowany pomnik, tudzież inny monument, przyniesie szczęście.

Kolejnym punktem był zabytkowy Hotel Pasaż, którego architektem byl, nie kto inny jak Polak - Lew Włodek. Ogromne wrażenie zrobiło na nas wnętrze, zwłaszcza bogato zdobiona fasada, gdzie znajduje się część handlowa tego przybytku. Kolejno nasi przewodnicy przestawili nam historię Opery Odeskiej, do której odbudowy po wielkim pożarze w 1873 r. przyczynił się polski architekt Feliks Gąsiorowski. Mieliśmy również możliwość zobaczenia wnętrza zabytkowej opery, w której znajduje się około $75 \mathrm{~kg}$ płatkowanego złota. Cennym doświadczeniem było uczestnictwo w wieczornym koncercie muzyki filmowej w wykonaniu orkiestry symfonicznej, w której składzie znajdowały osoby pochodzenia polskiego. 
We wtorek mieliśmy sposobność, w towarzystwie Pani Sonii, przebyć korytarze katakumb odeskich, które drążone u początku powstania miasta pozwalały wydobyć surowiec na budowę Odessy. Długość podziemnych ścieżek przekracza 2800 kilometrów, to więcej niż odległość między Poznaniem, a Odessą. Ukazuje to niewyobrażalną skalę przedsięwzięcia. Początkowo wszystko wydobywano manualnie, czynili to robotnicy (także pochodzenia polskiego) przy użyciu gigantycznych pił. Po tym jak kopalnia została zamknięta, wielokilometrowe korytarze stały się miejscem schronienia dla tutejszych grup przestępczych, zwłaszcza dla słynnej odeskiej szajki złodziejskiej. W części katakumb władze Odessy zorganizowały więzienie dla kobiet, a w drugiej połowie XX w. podziemne ścieżki wykorzystano na budowę schronu przeciwatomowego, którego wejścia ulokowano w nieoczywistych miejscach, nieopodal głównych ulic w specjalnie wybudowanych skromnych garażach. Następnie skierowaliśmy się ku dzielnicy Mołdawianka, jednej z najbiedniejszych dzielnic w Odessie, w kierunku Soboru Przemienienia Pańskiego, w którym mogliśmy uświadczyć typowych dla ornamentyki prawosławnej bogatych i złotych zdobień.

Po południu mieliśmy przyjemność przeprowadzić wywiad z przewodniczącą stowarzyszenia Polska Nuta, Panią Eugenią Fedczyszyną oraz z jej najbardziej zaangażowaną członkinią, Sonią Pajgert. Rozmowę rozpoczęliśmy od pytania o początki Polskiej Nuty. Joanna Strzelczyk, ówczesny konsul generalny, 3 V 2013 r. zatwierdziła powstanie polskiego stowarzyszenia pod nazwą Polska Nuta, natomiast rejestracja miała miejsce 25 października tegoż roku. Fundamentem, na którym budowano stowarzyszenie, stał się nowopowstały chór, który przyciągał do siebie wielu chętnych ludzi. Formalnie stowarzyszenie liczy sobie około 500 osób, ale zaangażowanych członków jest blisko 120. Od początku tego przedsięwzięcia problem stanowiło lokum, w którym swobodnie mogłaby działać Polska Nuta, przede wszystkim z uwagi na wysoką cenę najmu w Odessie i słabe warunki lokalowe. Działalność grupy opiera się na chórze, ale istnieje też studio artystyczne złote ręce, prowadzone są lekcje języka polskiego, a co sobotę wykłady z historii Polski, które polegają na wyborze ważnej dla dziejów naszego kraju daty, wokół której budowana jest dyskusja. Organizowane są konkursy wiedzy o Polsce m.in. 101 pytań o Polskę, zorganizowany na 101. rocznicę Święta Niepodległości.

W Odessie działa Szkoła Podstawowa nr 121, w której lekcje prowadzone są m.in. w języku polskim. Na Uniwersytecie im. Ilji Miecznikowa do tej pory istniała specjalizacja języka polskiego, niestety w tym roku na nabór odpowiedziało jedynie dwoje studentów, a sam kierunek zawieszono. Stowarzyszenie czynnie zabiega o źródła w miejscowych archiwach dotyczące przybyłych na te ziemie Polaków. Dzięki 
uprzejmości Pani Eugenii mieliśmy możliwość wysłuchania kilku przejmujących opowieści o Polakach, które udało się odnaleźć w stosach źródeł odeskich archiwaliów. Pani Eugenia zwróciła uwagę na działalność kościoła polskiego w Odessie i zaangażowanie ks. kanonika Jana Dargiewicza, który pełni posługę na tej ziemi już 12 lat i czynnie współpracuje z polskim stowarzyszeniem. Towarzystwo trudni się renowacją i pielęgnacją polskich grobów na odeskich cmentarzach. Organizowane są akcje społeczne, w których mniejszość polska dba o miejsca pochówków swoich zmarłych rodaków.

Jednym z kłopotów polskich grobów w odeskich nekropoliach są nazwiska Polaków często przeinaczone z uwagi na zapis cyrylicą. Do polskości przyznaje się ok. 3 tys. osób, a wiele rodzin wciąż zwraca się do polskich stowarzyszeń chcąc udowodnić swój polski rodowód. Jako jedyne stowarzyszenie na Ukrainie, Polska Nuta obchodzi 23 marca dni polsko-ukraińskiej przyjaźni, które stanowią kalkę święta przyjaźni polsko-węgierskiej. W trakcie wywiadu zaszczyciła nas swoją obecnością Pani Małgorzata, nauczycielka języka polskiego, która dzięki Ośrodkowi Rozwoju Polskiej Edukacji za Granicą ma możliwość kształcenia nie tylko tutejszej młodzieży, ale również osób starszych i ludzi niezwiązanych narodowościowo z Polską. O swojej pracy opowiedziała nam także Pani Sonia, która jest bardzo zaangażowana w życie artystyczne towarzystwa - jest też absolwentką poznańskiego Uniwersytetu Artystycznego. Jest autorką wierszy, okładek książkowych, przeprowadziła również renowację drogi krzyżowej w Katedrze Wniebowstąpienia Najświętszej Maryi Panny, do której ściągnięto specjalistów z Polski. Warto nadmienić, że kultura nie jest na tych ziemiach wyłącznie pielęgnowana, ona wciąż powstaje, chciałoby się rzec, że ona żyje. Stowarzyszenie prężnie działa w mediach społecznościowych, na takich witrynach jak Facebook czy YouTube publikują swoje wszelkie osiągnięcia, do których zapoznania serdecznie zapraszamy.

W środę udaliśmy się do Parku Preobrażeńskiego, gdzie niegdyś znajdował się pierwszy cmentarz katolicki. Na terenie parku ulokowany jest Khram Dymytryya Solunskoho - skromny obiekt sakralny. Następnym miejscem na naszej trasie był zabytkowy dworzec kolejowy. Nie można jednoznacznie określić stylu, w którym budynek został zbudowany, stanowi on kompozycję wielu technik architektonicznych. W dalszej kolejności udaliśmy się do Monasteru św. Pantelejmona oraz Monasteru św. Eliasza. Ośrodki te wyróżniały się bogactwem zdobień, nawet na tle prawosławnych świątyń. Następnie skierowaliśmy się do Katedry Wniebowzięcia Najświętszej Maryi Panny. Dużym zaskoczeniem było ulokowane w nawie bocznej tabernakulum. Dzięki uprzejmości księdza Witolda mieliśmy przyjemność wysłuchania wykładu 
w synagodze Beit Chabad. Zapoznaliśmy się z doktrynami wiary religii żydowskiej, historią Żydów w Odessie, ich udziałem w tworzeniu miasta i wkładem w życie gospodarcze. W drodze powrotnej do katedry mijaliśmy Synagogę Brodzką, gdzie dzisiaj znajduje się archiwum. W katedrze zaszczycił nas swą obecnością Kapelan Polonii, ksiądz kanonik Jan Dargiewicz. Duchowny przedstawił nam zarys historii miasta i podkreślił znaczący udział rodzin polskich u początków budowy Odessy, po czym płynnie przeszedł do historii kościoła katolickiego na tamtejszej ziemi. Historię ks. Jan zaczął od kasaty klasztorów i wyjątku, jaki poczyniła Katarzyna II, caryca Rosji, zachowując jezuitów, którzy od tej pory stali się jej doradcami. Pokłosiem tego miała być Odessa, ponieważ to oni mieli wskazać to miejsce jako strategiczny punkt do umocnienia obrony przed Imperium Osmańskim. Katolicy w tym mieście dostali kwartał ziemi, którą mogli przeznaczyć na budowę swojej świątyni. Pierwszy kościół był drewniany, a jego ściany kończyły się w miejscu, gdzie współcześnie znajdują się filary katedry. W latach 1844-1853 z inicjatywy księdza Grzegorza Razutowicza rozbudowano dotychczasowy kościól, a wkład w budowę mieli m.in. polski architekt Feliks Gąsiorowski i Włoch Francesco Morandi. W katedrze możemy znaleźć relikwie św. Faustyny, ofiarowaną przez Piusa IX marmurową chrzcielnicę, obrazy drogi krzyżowej liczące po ok. 200 lat (prócz dwóch, jeden ma ok. 300 lat i przedstawia Utrzymywanie Jezusa oraz najmłodszy obraz, Spotkanie z Matka Boża, który wierni wykonali sami, za płótno biorąc worek od ziemniaków). W czasie, gdy Ukraina była jedną z republik radzieckich świątynie przemianowywano na halę sportową, była to typowa praktyka władz komunistycznych, dążących do ateizacji ludności zależnej od swej władzy. Duchowny opowiadał nam o tym, jak skakano w dal w miejscu pochówku biskupa Wincentego Lipskiego, którego ciało złożono między kolumnami w katedrze. Podczas tego okresu straty były duże, sprzedano organy, wybudowano dodatkowy strop, rozkradziono część z dębowych ław, a konfesjonały przerobiono na kioski (część z ław i jeden konfesjonał zachowały się w Kościele św. Piotra, który niedawno otrzymał status bazyliki mniejszej). Proces odbudowy Katedry Wniebowzięcia Najświętszej Maryi Panny po laicyzacji sowieckiej był karkołomny, potrzebny był generalny remont świątyni. Sprowadzono lichtarze z Polski, organy z Białegostoku, zlikwidowano wybudowany strop, a ostatnio przeprowadzono renowację wspomnianej już drogi krzyżowej. W świątyni, oprócz biskupa Lipskiego, złożono też ciało Francuza Comte De Langerona, który wspierał finansowo kościół za swego życia.

Aktualnie od 2002 r. katedra należy do diecezji odesko-symferopolskiej, którą utworzył Jan Paweł II. Następnie ks. Jan zaprowadził nas do wspomnianego wcze- 
śniej kościoła św. Piotra, po którym nas oprowadzono i odmówiliśmy wspólnie modlitwę. Po tym przeszliśmy do domu parafialnego na poczęstunek i rozmowę o aktualnym oraz przeszłym stanie kościoła katolickiego w obwodzie odeskim. Ks. Jan opowiedział nam o okolicznościach jego przybycia do obwodu odeskiego, gdzie dziś pełni posługę kapłańską. Poruszony został wątek relacji z wyznaniem prawosławnym. Wytłumaczono nam, że oba wyznania wspierały się, gdy po II wojnie światowej Ukraina była jedną z republik radzieckich i wiele osób, nie mogąc kultywować tradycji religijnych zgodnie z własnym wyznaniem, praktykowało w innym obrządku. Stąd wiele prawosławnych osób, które były ochrzczone zgodnie z tradycją katolicką i odwrotnie. Rozmawialiśmy również o ateizacji za czasów komunistycznych, w których kościół przeżywał trudne chwile. W tym okresie nie prowadzono ksiąg parafialnych, zamykano kościoły, nie odbywały się święcenia kapłańskie. Ksiądz przy okazji rozmów o uciśnionym kościele po 1945 r. wspomniał o trudnej sytuacji Polaków, którzy zamieszkują współcześnie półwysep Krymski wcielony do Federacji Rosyjskiej w 2014 r. Zamieszkująca tam mniejszość polska ma utrudnione kontakty nie tylko z kościołem, ale i z państwem ze względu na zamknięty konsulat. Z ks. Janem rozstaliśmy się przy pomniku tzw. Łapówki, który zbudowano na część korupcji, jakiej dopuścili się kupcy odescy na wieść o zaprzestaniu dotacji na rozbudowę miasta portowego przez nowo wybranego cara Pawła I. Jest to wspomniana już wcześniej łapówka w postaci pomarańczy, którą wysłano na wozach do samego cara z prośbą o dalszy rozwój miasta. Jak nietrudno się domyślić inwestycja zaowocowała, a Odessa mogła dalej rozwijać się. Monument przedstawia pomarańczę, z której wykrojona jest ćwiartka tego owocu, gdzie znajduje się postać cara Pawła I trzymającego w ręku pomarańczę. Owoc na wozie ciągną konie, a na szczycie tego pomnika widzimy klasycystyczne budowle miasta.

21 XI 2019 r., na zaproszenie Międzynarodowego Uniwersytetu Humanistycznego w Odessie (МежАународный Гуманитарный Университет) uczestniczyliśmy w okrągłym stole dotyczącym dialogu polsko-ukraińskiego. W obradach wzięli udział przedstawiciele uczelni odeskich: Jego Magnificencja, Rektor МГУ dr hab. K. Gromovenko, kierownik Wydziału Historii Ukrainy K. Ushinsky, dr nauk ekonomicznych A. Krasnozhon, dr nauk, profesor Wydziału Historii Ukrainy ONU I.I. Miecznikow, prof. T. Goncharuk, profesorowie nadzwyczajni Wydziału Historii i Etnografii Ukrainy ONPU O. Melnyk i A. Fedorova, Dziekan Wydziału Lingwistyki i Tłumaczeń МГУ, dr filologii, prof. M. Zubov, przedstawiciel МГУ, dr nauk, doc. V. Pischemukha. Stronę polską reprezentowali: prof. UAM dr hab. Agnieszka Sawicz, prof. UAM dr hab. Piotr Okulewicz i prof. dr hab. Stanisław Jankowiak. Roz- 
mowy dotyczyły stosunków polsko-ukraińskich oraz perspektyw ich rozwoju. Jako studenci także przedstawiliśmy swoją opinię na ten temat, konfrontując ją z poglądami koleżanek i kolegów ze strony ukraińskiej. Po zakończeniu obrad okrągłego stołu nawiązaliśmy kontakt z samorządem studenckim ww. uczelni. W wyniku współpracy między naszymi uczelniami, chcielibyśmy wspólnie zorganizować konferencje naukową w murach naszego uniwersytetu, która dotyczyłaby tematu łączącego oba nasze narody. Efektem konferencji będzie m.in. publikacja zbiorowa poświęcona stosunkom polsko-ukraińskim. Pozwoli to na budowanie wzajemnych relacji, co może zaowocować większą świadomością problemów sąsiedniego kraju i da możliwość stworzenia płaszczyzny porozumienia.

Po konferencji naukowej naszym celem było Muzeum Sztuki Wschodu i Zachodu. We wnętrzu znajdowały się zabytkowe schody z marmuru karrarskiego, których budowa była wielkim przedsięwzięciem finansowym. Niesamowity efekt wizualny wywoływał brak asekuracji tychże schodów w postaci jakiejkolwiek kolumnady czy też zwykłych podpór. Dokonano tego dzięki głębokim żłobieniom w ścianach, w których mocowano schody oraz niespotykanym ułożeniem stopni, każdy ze schodków opierał swój ciężar na poprzednim. Na piętrze muzeum znajdowały się liczne obrazy, w większości dziewiętnastowieczne. Muzeum posiadało zasoby dzieł inkrustowanych oraz drewniane eksponaty, na które nakładano różne rodzaje drewna tworzące elementy dekoracyjne, zabieg taki nazywamy intarsją. Ułożenie pomieszczeń w obiekcie tworzyło anfiladę, dzięki której budynek wydawał się przestrzennie większy. Na parterze znajdywały się liczne repliki rzeźb charakterystycznych dla kultury antycznej. Na naszej drodze tego dnia pojawił się kolejny obiekt muzealny, którym było Muzeum Archeologiczne, szczególnie związane z polskością, gdyż architektem był wspominany już wcześniej Feliks Gąsiorowski. Muzeum posiada bogatą kolekcję odnoszącą się do kultur prehistorycznych i antycznych, zwłaszcza podziw wzbudza wystawa związana z kulturą egipską.

Ostatniego dnia udaliśmy się na teren zakładów Pressmasz, gdzie w czasach, gdy Ukraina była jedną z republik radzieckich, postawiono pomnik Włodzimierza Lenina. W ramach dekomunizacji we współczesnym państwie ukraińskim przemodelowano postać jednoznacznie związaną z komunizmem, na postać, która zdecydowanie utożsamiana jest z zachodem - Darth Vaderem, jedną z głównych postaci sagi Gwiezdnych Wojen. Następnie udaliśmy się na drugi cmentarz chrześcijański w Odessie. Na terenie nekropolii chcieliśmy skupić się na obserwacji polskich miejsc pochówków, które wyróżniały się na tle innych grobów, najczęściej prawosławnych, gdyż tylko na nich stawiano znicze, charakterystyczne dla naszej kultury. 
22 XI 2019 r., uczestniczyliśmy również w seminarium memuarystycznym zorganizowanym przez Związek dziennikarzy Ukrainy w Odessie. Naszą uczelnie reprezentowała prof. UAM dr hab. Agnieszka Sawicz, której wystąpienie było poświęcone perspektywom współpracy polsko-ukraińskiej oraz współpracy pomiędzy środowiskami akademickimi. W drodze do centrum miasta wstąpiliśmy do Soboru Zaśnięcia Matki Bożej, w której mogliśmy być świadkami odprawianego nabożeństwa w jednej z naw bocznych świątyni. Następnie skierowaliśmy się pod pomnik patrona naszej uczelni, Adama Mickiewicza, który przypomina o twórczości polskiego wieszcza zachwycającego się krajobrazem nadczarnomorskim. Ostatnim punktem tego dnia było Muzeum Potockich, które niegdyś budowano na rezydencje Seweryna Potockiego, polskiego szlachcica, który po rozbiorach Rzeczypospolitej, wierny carowi trafil nad tereny czarnomorskie. Potocki jednak nie doczekał się ukończenia budowli, a spadek po nim przejęła jego daleka krewna Olga Potocka, córka Szczęsnego Potockiego. Muzeum posiada bogatą kolekcję obrazów, w których przejawia się często motyw historii Odessy. Znajdziemy tu również rzeźby nie tylko kamienne, ale również drewniane oraz liczną wystawę sztuki współczesnej.

Pobyt w Odessie unaocznił nam, jak wielki udział w budowie Odessy mieli Polacy, można by nawet rzec, że to miasto stoi na polskich fundamentach, dosłownie i w przenośni. Znaczna część starego miasta została zaprojektowana przez polskich architektów, m.in. Feliksa Gąsiorowskiego, Lwa Włodka. Spotkania z mniejszością polską zamieszkującą Odessę pozwoliły nam na poznanie historii tego miasta z polskiej perspektywy. Wielu uczestników naszego projektu, tutaj na obczyźnie, widząc Polaków, którzy z dala od macierzystego kraju dbają o narodowe dziedzictwo, na nowo odczuwała zachwyt Polską, jej tradycją i kulturą. Spędzając czas z mniejszością polską, można było wyczuć więź, która łączy tych ludzi, spaja ich narodowość, i dumę ze swego pochodzenia. Niezwykle kształtujące naszą opinię o narodowości polskiej w Odessie były wywiady z członkami Narodowo-Kulturalnego Stowarzyszenia Polaków Polska Nuta oraz z przedstawicielami polskiego kościoła katolickiego. Po raz kolejny wyjazd naukowy na terytorium Ukrainy, tym razem nad tereny czarnomorskie, sprawia, że ulega weryfikacji nasze wyobrażenie, tym razem o wschodniej części sąsiadującego z nami państwa. Odessa podobnie jak Lwów jest wielokulturowym miastem, przenikają się tu różne narodowości posługujące się odmiennymi językami. Taka mozaika narodowościowa tworzy swoistą kompozycje kulturalną, a to wszystko buduje niepowtarzalny charakter tego miasta. Zaproszenie i udział w okrąglym stole na МГУ zmusiło nas do refleksji o często skomplikowanej historii relacji między naszymi narodami. Spotkaliśmy się tam z przedstawicielami kadry 
profesorskiej odeskich uniwersytetów i z naszymi ukraińskimi rówieśnikami, by rozmawiać na temat poprawy relacji stosunków polsko-ukraińskich. Mamy głęboką nadzieję, że doprowadzi to do współpracy między naszymi uczelniami, a finalnie wpłynie to pozytywnie na poprawę komunikacji dwóch narodowości, które wbrew pozorom łączy wiele wspólnego.

Opiekunami drugiej części projektu byli:

- Prof. UAM dr hab. Agnieszka Sawicz,

- Prof. dr hab. Stanisław Jankowiak,

- Prof. UAM dr hab. Piotr Okulewicz.

Joanna Przybylska

Wydział Historii

Uniwersytet im. Adama Mickiewicza w Poznaniu

ul. Uniwersytetu Poznańskiego 7

61-614 Poznań

Marcin Janicki

Wydział Historii

Uniwersytet im. Adama Mickiewicza w Poznaniu

ul. Uniwersytetu Poznańskiego 7

61-614 Poznań

Jakub Nitecki

Wydział Historii

Uniwersytet im. Adama Mickiewicza w Poznaniu

ul. Uniwersytetu Poznańskiego 7

61-614 Poznań

Nadesłany 20 VII 2019

Zaakceptowany 10 VIII 2019 